\title{
The Impacts of Website Characteristics and Customer Participation on Citizenship Behaviors: The Mediating Role of Co-Creation Experience in Virtual Brand Communities
}

\author{
Yong Zhang, Lu Chen \\ School of Management, Jinan University, Guangzhou, China \\ Email: hi2014lu@126.com
}

How to cite this paper: Zhang, Y., \& Chen, L. (2017). The Impacts of Website Characteristics and Customer Participation on Citizenship Behaviors: The Mediating Role of Co-Creation Experience in Virtual Brand Communities. Advances in Applied Sociology, 7, 151-164.

https://doi.org/10.4236/aasoci.2017.74009

Received: March 10, 2017

Accepted: April 15, 2017

Published: April 18, 2017

Copyright $\odot 2017$ by authors and Scientific Research Publishing Inc. This work is licensed under the Creative Commons Attribution International License (CC BY 4.0).

http://creativecommons.org/licenses/by/4.0/

\begin{abstract}
More and more enterprises organize co-creation activities in virtual brand community to allow customers to participate in new products or new service development process. Involved in those activities, customers obtain experience value, which can make them have sense of achievement. Does this cocreation experience promote the formation of loyalty, such as customer citizenship behaviors? Dowebsite characteristics influence the co-creation experience? The study examines the relationship between co-creation experience to citizenship behaviors and the impact of website characteristics as well as customer participation to co-creation experience. Based previous research, the study builds structural equation model and conducts empirical analysis. The results show that the affection-relevant clues of the site characteristics and customer participation have a positive impact on three dimensions of the experience, and the task-relevant clues have a positive influence on the hedonic experience and social experience. The two dimensions of co-creation experience have a significant positive impact on citizenship behaviors and have a mediating effect.
\end{abstract}

\section{Keywords}

Customer Participation, Website Characteristics, Co-Creation Experience, Citizenship Behaviors, Virtual Brand Communities

\section{Introduction}

Virtual brand community is a typical platform of value co-creation, and for customers to gain brand experience. Customers' experience gained from value co- 
creation activities has been paid attention to by academics. Most of the existing research is qualitative. Customer citizenship behavior is a kind of behavior that the customers voluntarily make benefits for the enterprise, which can provide useful enlightenment for the enterprise to manage the customer behavior in virtual brand community and develop the customer relationship. But at present, this concept has not yet attracted enough attention in the field of virtual brand community research. Hence, in the context of virtual brand community, this paper discusses the Impact of website characteristics, customer participation and co-creation experience on citizenship behaviors.

\section{Literature Review and Research Hypotheses}

\subsection{Customer Participation and Co-Creation Experience}

In virtual brand community research, customer participation mainly refers to posting and browsing activities (Koh \& Kim, 2007). Prahalad and Ramaswamy (2000) argue that the core idea of value co-creation is to guide the active participation of customers and the essence of value co-creation is to create experience value for customers. Customer participation is the premise of value co-creation and value co-creation is an important manifestation of customer participation behavior (Van Doorn et al., 2010). With the theory of value co-creation coming out, it is found that experience is no longer a single behavior of the user, but the enterprise provides conditions for the consumer to create experience initiatively according to their own individual needs (Prahalad and Ramaswamy, 2004). Value co-creation describes how customers actively participate in the design and development of products or services, and how customers interact with businesses or other stakeholders in the consumer sector (Payne, 2008). Co-creation experience is the mental state that the customer obtains in the process of participating in the value creation process (Zhang et al., 2015). On the dimensions of the experience, Gentile et al. (2007) argue that the experience includes social dimension, functional dimension, and emotional dimension. Verleye (2015) divided co-creation experience into six dimensions: hedonic experience, cognitive experience, social experience, personal experience, pragmatic experience and economic experience. Based on the above research, this study divides the cocreation experience into three dimensions: hedonic experience, cognitive experience and social experience.

Customer participation in virtual brand communities can be interactive or non-interactive. Interactive participation is sharing information or responding to other members' needs, which is a positive participation. Non-interactive participation is a simple view or simply read the contents of the community, which is seen as a passive participation. The nature of the experience is a psychological state of the consumer and consumers are the core and determinants of value co-creation. Obviously, community members' different levels or stages of participation have different effects on the dimensions of the experience. On the basis of this discussion, the study hypothesizes as following:

H1a: Customer participation has a significant positive influence on the cus- 
tomer's hedonic experience.

H1b: Customer participation has a significant positive influence on the customer's cognitive experience.

H1c: Customer participation has a significant positive influence on the customer's social experience.

\subsection{Website Characteristics and Co-Creation Experience}

Website characteristics refer to a variety of features of the site to meet the needs of users. Huizingh (2000) pointed out that a website can be divided into two main parts: website content and website design. Website content is a wide range of information and transactions and entertainment contained by the site; the site design refers to a website how to arrange and present information on how to use the site to the user, in order to let them use easily. Eroglu et al. (2001) suggests that the environmental cues of the website would affect the behavior of the consumer to approach or evade; he divides the site characteristics into high task-relevant clues and low task-relevant clues. Task-related clues are information that are directly related to the completion of shopping task, such as product description and other text information, as well as commodity pictures and other image information. Low-related clues refer to information not directly related to the task, such as website's color, boundaries, background and animation. Parboteeah et al. (2009) further divided the site features into task-related cues and affection-relevant cues. They proposed those network environmental factors can influence customer behavior.

In a virtual brand community, website characteristic is a kind of customer perceived value. With prominent features, the virtual brand community can attract and encourage users to log in repeatedly, enjoy the services they provide and participate in activities. The interface in the web design has an impact on the ease of use of the site. According to the Technology Acceptance Model (TAM), the perceived ease of use of the site will affect the attitude of consumers using the site. Diverse task-related clues can significantly increase their happiness by satisfying the curiosity of customer to brand-related information (Muniz et al., 2001). Task-relevant clues make customers experience the improving ability, and thus a sense of excitement (Nambisan et al., 2009). Therefore, this study proposes the following assumptions:

H2a: Task-relevant clues have a significant positive impact on the customer's hedonic experience.

H2b: Task-relevant clues have a significant positive impact on the customer's cognitive experience.

$\mathrm{H} 2 \mathrm{c}$ : Task-relevant clues have a significant positive impact on the customer's social experience.

Affection-relevant cues indicate the customer's perception of the aesthetic beauty of the brand website, which affects the customer's thoughts and actions. Visual design is a key feature of the site and can influence customer's perception and experience (Liu et al., 2013). At the same time, the visual characteristics of 
the site were found to have a significant impact on the customer's first impression (Lindgaard, 2006). From the point of view of information processing, visual attraction can arouse customer greater attention, like a conditioned reflex. A highly appealing website can evoke the customer more detailed memory, which has an impact on the cognitive experience; the familiarity of the interface of the community increase customer's switching costs, which increase the customer's dependence and sense of identity on community (Schau, 2009; Ren et al., 2012; Liang et al., 2011). In addition, the definition of affection-related clues contains the meaning that can bring happiness and enjoy to the customer, and the beautiful website page gives the customer an intuition pleasure. Hence, the study proposes:

H3a: Affection-relevant clues have a significant positive impact on the customer's hedonic experience.

H3b: Affection-relevant clues have a significant positive impact on the customer's cognitive experience.

H3c: Affection-relevant clues have a significant positive impact on the customer's social experience.

\subsection{Co-Creation Experience and Citizenship Behaviors}

The concept of customer citizenship behavior is derived from the term "organizational citizenship behavior" in organizational behavior. Gruen (1995) defines it as a kind of customer voluntary behavior which is beneficial to the organization. Bettencourt (1997) argues that enthusiastic participation in the activities organized by enterprises, making recommendations on the production process and being loyal to enterprises is the customer's citizenship behavior. Keh \& Chi (2001) found that when accept the service provided by the company, customers would have different behaviors according their different perception of the enterprise, including in-role behavior and extra-role behavior. In-role behavior is action took necessarily by customers to meet their own needs; if customers identify the company, they would have voluntary and non-mandatory behavior that is extra-role behavior. Similarly, Ahearne et al. (2005) points out that when customers have a strong sense of identity in the enterprise, they may ignore their own interests and make positive contributions to the business. Rosenbaum and Massiah (2007) believe that customer citizenship behavior enhance corporate performance and customers' feedback benefit to promote the service quality. Groth (2005) summarized recommend, feedback to the organization and help other customers as customer citizenship behaviors. Bove et al. (2009) divided customer citizenship behaviors into more detailed dimensions: participation, relationship presentation, understanding, flexibility, service promotion, feedback, and management of other customers. Yi and Gong (2013) take the service industry as research object, and suggest that customer citizenship behavior contain feedback, advocacy, help and patience.

Customer citizenship behavior including pointing out the existing problems of the organization, providing innovative ideas and constructive advice on the 
direction of improvement, recommending and helping other customers initiatively is important for the enterprise to improve the management of the community and the quality of the products or services. And customer citizenship behavior is affected by the perception, interests and identity of the enterprises. Co-creation experience is consumer's psychological state in the process of interaction with the enterprise. Therefore, we propose the following assumptions:

H4a: The customer hedonic experience has a significant positive influence on customer citizenship behavior.

H4b: The customer cognitive experience has a significant positive influence on customer citizenship behavior.

H4c: The customer social experience has a significant positive influence on customer citizenship behavior.

H5: Co-creation experience has a mediating effect between site characteristics, customer participation and citizenship behavior.

\section{Research Design}

\subsection{Measurement}

As suggested above, Figure 1 shows logical relationships among the variables and research model constructed according to the S-O-R framework. In this study, the questionnaire base on existing scales and is adjusted according to the research context. Customer participation was measured using four items adapted from Yi and Gong (2012). Website characteristics were measured from two aspects: task-related clues and affection-related clues, using four items adapted from Parboteeah et al (2009). Co-creation experience has three dimensions: hedonic experience, cognitive experience and social experience. Measurement items for those three dimensions were adapted from Verleye (2015) and Zhang et al. (2015). Hedonic experience was measured by four questions; cognitive experience was measured with five questions; and social experience was measured with three questions. Customer citizenship behavior was measured by adapting items used by Groth (2005). The Likert-7 scale was used to measure variables (1 $=$ "completely disagree" and $7=$ "completely agree"). Table 1 presents the measure items of every variable.

\subsection{Data Collection}

The study regards the mobile phone brand community members as the survey

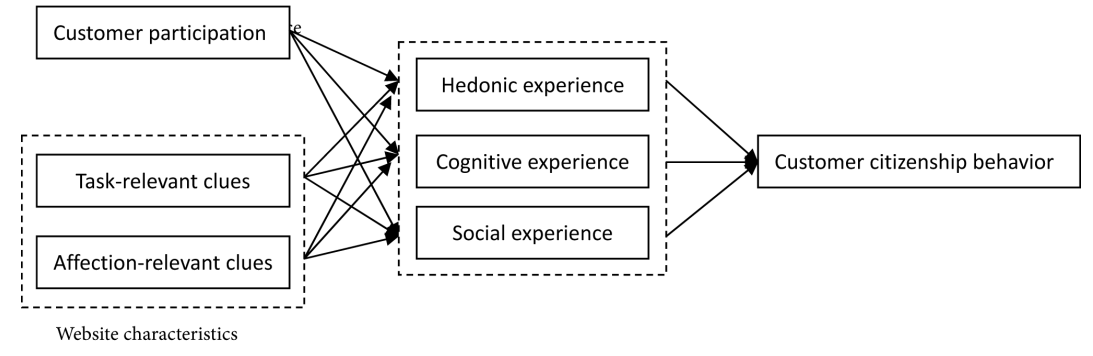

Figure 1. Research model diagram. 
Table 1. Items of variables.

\begin{tabular}{|c|c|}
\hline Variable & Items \\
\hline $\begin{array}{l}\text { Customer participation } \\
\text { (Yi \& Gong, 2013) }\end{array}$ & $\begin{array}{l}\text { CP1 I often launch topics in the community } \\
\text { related to brand or products } \\
\text { CP2 I am actively involved in community-organized activities } \\
\text { CP3 I often post in the community and get someone else to respond } \\
\text { CP4 I often communicate or build relationships with other members }\end{array}$ \\
\hline $\begin{array}{l}\text { Website characteristics: } \\
\text { task-relevant clues } \\
\text { (Parboteeah et al., 2009) }\end{array}$ & $\begin{array}{l}\text { IFT1 The information on the website is useful } \\
\text { IFT2 The information on the website fully meet my information needs } \\
\text { IFT3 The information on the website is almost } \\
\text { always what I need to solve problems }\end{array}$ \\
\hline $\begin{array}{l}\text { Website characteristics: } \\
\text { affection-relevant clues } \\
\text { (Parboteeah et al., 2009) }\end{array}$ & $\begin{array}{l}\text { PVA1 The website is visually pleasing } \\
\text { PVA2 The website has a pleasing visual design } \\
\text { PVA3 The website is visually appealing }\end{array}$ \\
\hline $\begin{array}{l}\text { Co-creation experience: } \\
\text { hedonic experience } \\
\quad \text { (Verleye, 2015; } \\
\text { Zhang et al., 2015) }\end{array}$ & $\begin{array}{l}\text { HE1 I am happy and relaxed in the process of } \\
\text { participating in community activities } \\
\text { HE2 The process of participating in the activities of } \\
\text { the community is interesting and makes me happy } \\
\text { HE3 I got a lot of excitement and satisfaction } \\
\text { from participating in community activities } \\
\text { HE4 The problem being solved and the } \\
\text { creative ideas generating make me enjoy }\end{array}$ \\
\hline $\begin{array}{l}\text { Co-creation experience: } \\
\text { cognitive experience } \\
\text { (Verleye, 2015; } \\
\text { Zhang et al., 2015) }\end{array}$ & $\begin{array}{l}\text { CE1 In the process of participating in the activities, I improved the skills } \\
\text { CE2 Co-creation activities give me professional knowledge on products } \\
\text { CE3 I play a role in the process of co-creation activities } \\
\text { CE4 participating in activities make me keep up with new ideas } \\
\text { CE5 participating in activities stimulate my thoughts }\end{array}$ \\
\hline $\begin{array}{l}\text { Co-creation experience: } \\
\text { social experience } \\
\quad \text { (Verleye, 2015; } \\
\text { Zhang et al., 2015) }\end{array}$ & $\begin{array}{l}\text { SE1 Participating in community activities expands my social network } \\
\text { SE2 Participating in community activities strengthens } \\
\text { my close ties with the community } \\
\text { SE3 Participating in activities enhances my sense } \\
\text { of belonging to the community }\end{array}$ \\
\hline $\begin{array}{l}\text { Customer citizenship } \\
\text { behavior } \\
\text { (Groth, 2005) }\end{array}$ & $\begin{array}{l}\text { CB1 I will help others search for the brand's product information } \\
\text { CB2 I will explain to others how to use the products or services properly } \\
\text { CB3 I often recommend products of the brand to colleagues or family } \\
\text { CB4 I will coordinate the brand company with survey } \\
\text { CB5 I will make suggestions for improvement to the brand community }\end{array}$ \\
\hline
\end{tabular}

object, using the way of filling in online questionnaire for data collection. The official survey was conducted from September 20, 2016 to October 12, 2016, and the questionnaire was sent to the Millet community, Wei Feng net, Huawei pollen club through the third-party questionnaire website platform. The respondents must be involved in the co-creation activities and they have rewards in order to improve the response rate of online questionnaires. A total of 417 questionnaires were collected and 315 valid questionnaires were obtained. The valid response rate is $84.41 \%$. The effective sample of this study is more than 200 , which meets the size requirement of medium sample, which can guarantee the stability of the empirical study.

\section{Data Analysis}

\subsection{Sample Characteristics}

According to descriptive statistical analysis results of the samples, the number of 
male participants accounting for $65.1 \% ; 51.2 \%$ of the respondents are $19-25$ years old, and $25.1 \%$ of the samples are 26 - 30 years old. Most of samples are young people who are under the age of 30 , and this is roughly the same as the age distribution of Internet users in China. The education level is more average, but the majority of respondents are undergraduate education. As for occupation, the proportion of the students and employees, are respectively about 33\%. The participants who have been members of the community for one to two years accounted for $23.7 \% ; 11.6 \%$ for two to three years, and $15.4 \%$ for more than third years. The subjects who visit the community website one to two times a week accounted for $30.2 \%$; 3 to 4 times for $24.2 \%$, and more than 5 times a week for $21.4 \%$. Based on the above sample characteristics analysis results, the data collected through questionnaire is in accordance with the actual situation, and suitable for the next step analysis.

\subsection{The Reliability and Validity Examination}

The study use SPSS18.0 to analyze the reliability and validity of the questionnaire, and the result in Table 2 shows that the Cronbach's a coefficient of the whole questionnaire was 0.981 , and the Cronbach's a coefficients of each variables is above 0.8 , which indicated that the questionnaire had good reliability and high intrinsic consistency. Scale reliability is acceptable. As shown in Table 2 , the factor loading of all variables in this study are more than 0.7 , which is higher than 0.5 , and composite reliability values are higher than 0.7 . The average variance extracted (AVE) reach more than 0.5 , and it shows that the convergent validity of each variable meets the requirements.

As shown in Table 3, the diagonal bold numbers are the square root of the AVE value of each variable, and the non-diagonal numbers are the correlation coefficients of each variable. The square root of AVE of each variable in the study is larger than its correlation coefficient. The results showed that the model was well fitted $\left(\chi^{2}=264.252, \mathrm{DF}=94, \chi^{2} / \mathrm{DF}=2.811(p<0.05)\right.$; GFI $=0.892$; CFI $=0.950 ; \mathrm{NFI}=0.925 ; \mathrm{IFI}=0.953 ; \mathrm{RMSEA}=0.083)$. And then it is proved that the measurement model has good discriminant validity. In summary, the measurement of variables and the scale in this study have good reliability and validity.

\subsection{Hypotheses Tests}

According to the correction index (MI), and in view of the practice situation, this study adds the correlation path between the task-related clue and affection-related clue. As shown in Table 4, this experiment's analyzing results of the revised SEM all achieve the desired requirements, indicating the model moderately fitted the observed data.

Using Amos 17.0 statistical analysis software to analyze the sample data and carry out structural equation estimation, normalization coefficients and level of significance can be calculated. And then there are hypothesis test results and specific path coefficients (see Table 5). 
Table 2. Results of reliability test and confirmatory factor analysis of variables.

\begin{tabular}{|c|c|c|c|}
\hline Variable & Factor loading value & CR & AVE \\
\hline $\begin{array}{l}\text { customer participation } \\
\qquad(\alpha=0.881)\end{array}$ & $\begin{array}{l}0.785^{* * *} \\
0.835^{* * *} \\
0.733^{* * *} \\
0.842^{* * *}\end{array}$ & 0.913 & 0.747 \\
\hline $\begin{array}{l}\text { task-relevant clues } \\
\qquad(\alpha=0.840)\end{array}$ & $\begin{array}{l}0.797^{\star * *} \\
0.895^{\star * \star} \\
0.907^{\star * *}\end{array}$ & 0.875 & 0.702 \\
\hline $\begin{array}{l}\text { affection-relevant clues } \\
\qquad(\alpha=0.892)\end{array}$ & $\begin{array}{l}0.900^{\star * *} \\
0.901^{\star \star *} \\
0.862^{\star \star \star}\end{array}$ & 0.885 & 0.714 \\
\hline $\begin{array}{l}\text { hedonic experience } \\
\qquad(\alpha=0.893)\end{array}$ & $\begin{array}{l}0.812^{\star * \star} \\
0.905^{\star * *} \\
0.916^{* * *} \\
0.709^{\star * *}\end{array}$ & 0.941 & 0.838 \\
\hline $\begin{array}{l}\text { cognitive experience } \\
\qquad(\alpha=0.926)\end{array}$ & $\begin{array}{l}0.793^{\star * *} \\
0.807^{\star * *} \\
0.722^{\star * *} \\
0.814^{\star * *} \\
0.704^{* * *}\end{array}$ & 0.847 & 0.685 \\
\hline $\begin{array}{l}\text { social experience } \\
\qquad(\alpha=0.908)\end{array}$ & $\begin{array}{l}0.883^{* * *} \\
0.879^{* * *} \\
0.827^{* * *}\end{array}$ & 0.966 & 0.844 \\
\hline $\begin{array}{l}\text { Customer Citizenship Behavior } \\
\qquad(\alpha=0.873)\end{array}$ & $\begin{array}{l}0.913^{\star * *} \\
0.836^{\star * \star} \\
0.802^{\star * *} \\
0.893^{* * *} \\
0.729^{* * *}\end{array}$ & 0.861 & 0.693 \\
\hline
\end{tabular}

Note: ${ }^{* * *}$ The level of significance is less than $0.001(p<0.001)$.

Table 3. Results of the discriminant validity analysis.

\begin{tabular}{cccccccc}
\hline & 1 & 2 & 3 & 4 & 5 & 6 & 7 \\
\hline 1. customer participation & 0.864 & & & & & & \\
2. task-relevant clues & $0.68^{* * *}$ & $\mathbf{0 . 8 3 8}$ & & & & & \\
3. affection-relevant clues & $0.72^{* * *}$ & $0.56^{* * *}$ & 0.845 & & & & \\
4. hedonic experience & $0.69^{* * *}$ & $0.63^{* * *}$ & $0.81^{* * *}$ & 0.915 & & & \\
5. cognitive experience & $0.29^{* * *}$ & $0.44^{* * *}$ & $0.60^{* * *}$ & $0.62^{* * *}$ & 0.828 & & \\
6. social experience & $0.47^{* * *}$ & $0.59^{* * *}$ & $0.61^{* * *}$ & $0.76^{* * *}$ & $0.54^{* * *}$ & 0.919 & \\
7. citizenship behavior & $0.54^{* * *}$ & $0.68^{* * *}$ & $0.62^{* * *}$ & $0.64^{* * *}$ & $0.81^{* * *}$ & $0.69^{* * *}$ & $\mathbf{0 . 8 3 2}$ \\
\hline
\end{tabular}

Notes: ${ }^{* *} p<0.001$. 
Table 4. Analyzing results of the revised SEM.

\begin{tabular}{cccccccc}
\hline fit index & $\chi^{2} / \mathrm{df}$ & GFI & RMR & RMSEA & NFI & IFI & CFI \\
\hline result & 2.951 & 0.901 & 0.039 & 0.062 & 0.928 & 0.919 & 0.903 \\
expected result & $<3.0$ & $>0.9$ & $<0.05$ & $<0.08$ & $>0.9$ & $>0.9$ & $>0.9$ \\
\hline
\end{tabular}

Table 5. Results of hypotheses tests.

\begin{tabular}{|c|c|c|c|}
\hline hypotheses & $\begin{array}{l}\text { Standardized path } \\
\text { Coefficients }\end{array}$ & $p$ & results \\
\hline $\begin{array}{l}\text { H1a: Customer participation has a significant positive } \\
\text { influence on the customer's hedonic experience. }\end{array}$ & 0.660 & $* * *$ & supported \\
\hline $\begin{array}{l}\text { H1b: Customer participation has a significant positive } \\
\text { influence on the customer's cognitive experience. }\end{array}$ & 0.370 & $* * *$ & supported \\
\hline $\begin{array}{l}\text { H1c: Customer participation has a significant positive } \\
\text { influence on the customer's social experience. }\end{array}$ & 0.641 & $* * *$ & supported \\
\hline $\begin{array}{l}\text { H2a: Task-relevant clues have a significant positive } \\
\text { impact on the customer's hedonic experience. }\end{array}$ & 0.081 & * & supported \\
\hline $\begin{array}{l}\text { H2b: Task-relevant clues have a significant positive } \\
\text { impact on the customer's cognitive experience. }\end{array}$ & 0.025 & 0.575 & Not supported \\
\hline $\begin{array}{l}\text { H2c: Task-relevant clues have a significant positive } \\
\text { impact on the customer's social experience. }\end{array}$ & 0.140 & * & supported \\
\hline $\begin{array}{l}\text { H3a: Affection-relevant clues have a significant positive } \\
\text { impact on the customer's hedonic experience. }\end{array}$ & 0.531 & $* * *$ & supported \\
\hline $\begin{array}{l}\text { H3b: Affection -relevant clues have a significant } \\
\text { positive impact on the customer's cognitive experience. }\end{array}$ & 0.197 & $* * *$ & supported \\
\hline $\begin{array}{l}\text { H3c: Affection -relevant clues have a significant positive } \\
\text { impact on the customer's social experience. }\end{array}$ & 0.130 & $* * *$ & supported \\
\hline $\begin{array}{l}\text { H4a: The customer hedonic experience has a significant } \\
\text { positive influence on customer citizenship behavior. }\end{array}$ & 0.487 & $* * *$ & supported \\
\hline $\begin{array}{l}\text { H4b: The customer cognitive experience has a } \\
\text { significant positive influence on customer } \\
\text { citizenship behavior. }\end{array}$ & 0.076 & 0.411 & Not supported \\
\hline $\begin{array}{l}\text { H4c: The customer social experience has a significant } \\
\text { positive influence on customer citizenship behavior. }\end{array}$ & 0.576 & $* * *$ & supported \\
\hline
\end{tabular}

Notes: ${ }^{* *} p<0.001,{ }^{* *} p<0.01,{ }^{*} p<0.05$.

According to the results in Table 4, customer participation had a significant positive effect on hedonic experience $(\beta=0.660, p<0.001)$, the cognitive experience $(\beta=0.370, p<0.001)$, the social experience $(\beta=0.641, p<0.001)$, and thus H1a, H1b, H1c are supported by data. Apart from H2b, H2a and H2c are supported by data, that is task-relevant clues had a positive influence on the cognitive experience $(\mathrm{B}=0.081, p<0.05)$ and the social experience $(\beta=0.140, p$ $<0.05)$. Affection-relevant clues had a significant positive impact on hedonic experience $(\mathrm{B}=0.531, p<0.001)$, the cognitive experience $(\beta=0.197, p<0.001)$, the social experience $(\beta=0.130, p<0.001)$, and thus H3a, H3b, H3c are supported by data. In addition to $\mathrm{H} 4 \mathrm{~b}, \mathrm{H} 4 \mathrm{a}$ and $\mathrm{H} 4 \mathrm{c}$ are supported by data. The 
cognitive experience didn't have a significant effect on customer citizenship behavior, but the hedonic experience $(\beta=0.487, p<0.001)$ had a positive impact on customer citizenship behavior. And the social experience $(\beta=0.576, p<$ 0.001 ) had a significant positive impact on citizenship behavior.

\subsection{The Mediating Role of Co-Creation Experience}

This study utilized the BootStrap method which is the mediating effect test procedure proposed by Zhao et al. (2010) to test the mediating effect of the co-creation experience. Choose the sample size as 5000 , indirect effect in the $95 \%$ confidence interval includes 0 or not can determine whether the mediating effect is significant. As shown in Table 6, co-creation experience's total mediating effect in the impact of task-related clues on customer citizenship behavior is significant, because $95 \%$ confidence interval is 0.124 to 0.252 , and 0 is not included. The mediating effect of hedonic experience and social experience are significant, whose effect values are 0.105 and 0.089 respectively. The indirect effect of cognitive experience is not significant, because the $95 \%$ confidence interval $(-0.015$, 0.027) contain 0. Co-creation experience's total mediating effect in the impact of affection-related clues on customer citizenship behavior is significant, because $95 \%$ confidence interval is 0.156 to 0.273 , and 0 is not included. The mediating effect of cognitive experience is not significant because the $95 \%$ confidence interval $(-0.007,0.019)$ contain 0 . The indirect effect of co-creation experience on customer participation to citizenship behavior is significant since the $95 \%$ confidence interval is 0.215 to 0.302 (excluding 0 ). The hedonic experience and social experience have a significant indirect effect and their effect results are 0.135 and 0.089 respectively; while the indirect effect of cognitive experience was not significant because of $95 \%$ confidence interval $(-0.021,0.017)$ containing 0 . Therefore, co-creation experience has a mediating effect between website characteristics, customer participation and citizenship behavior, and H5 is supported.

Table 6. Analyzing results of the mediating effec.

\begin{tabular}{|c|c|c|c|c|c|c|c|c|c|}
\hline \multirow{3}{*}{ Mediating effect } & \multicolumn{3}{|c|}{$\begin{array}{l}\text { Task-relevant clues to } \\
\text { customer citizenship } \\
\text { behavior }\end{array}$} & \multicolumn{3}{|c|}{$\begin{array}{l}\text { Affection-relevant clues to } \\
\text { customer citizenship } \\
\text { behavior }\end{array}$} & \multicolumn{3}{|c|}{$\begin{array}{c}\text { Customer participation to } \\
\text { customer citizenship } \\
\text { behavior }\end{array}$} \\
\hline & & \multicolumn{2}{|c|}{$\begin{array}{l}\text { 95\% Confidence } \\
\text { Interval }\end{array}$} & \multirow{2}{*}{ effect } & \multicolumn{2}{|c|}{$\begin{array}{c}\text { 95\% Confidence } \\
\text { Interval }\end{array}$} & \multirow{2}{*}{ effect } & \multicolumn{2}{|c|}{$\begin{array}{l}\text { 95\% Confidence } \\
\text { Interval }\end{array}$} \\
\hline & e & $\begin{array}{l}\text { Lower } \\
\text { bound }\end{array}$ & $\begin{array}{l}\text { Upper } \\
\text { bound }\end{array}$ & & $\begin{array}{l}\text { Lower } \\
\text { bound }\end{array}$ & $\begin{array}{l}\text { Upper } \\
\text { bound }\end{array}$ & & $\begin{array}{l}\text { Lower } \\
\text { bound }\end{array}$ & $\begin{array}{l}\text { Upper } \\
\text { bound }\end{array}$ \\
\hline Total effect & 0.198 & 0.124 & 0.252 & 0.216 & 0.156 & 0.273 & 0.267 & 00.215 & 0.302 \\
\hline $\begin{array}{c}\text { cognitive } \\
\text { experience }\end{array}$ & 0.003 & -0.015 & 0.027 & 0.003 & -0.007 & 0.019 & 0.006 & -0.021 & 0.017 \\
\hline $\begin{array}{c}\text { Hedonic } \\
\text { experience }\end{array}$ & 0.105 & 0.061 & 0.152 & 0.063 & 0.036 & 0.114 & 0.135 & 0.058 & 0.169 \\
\hline $\begin{array}{c}\text { social } \\
\text { experience }\end{array}$ & 0.089 & 0.053 & 0.143 & 0.114 & 0.102 & 0.193 & 0.089 & 0.128 & 0.198 \\
\hline
\end{tabular}




\section{Discussion}

\subsection{Discussion of Results}

The results show that the affection-relevant clues of the site characteristics and customer participation have a positive impact on three dimensions of co-creation experience: hedonic experience, cognitive experience, social experience; the task-related clues have a positive influence on the hedonic experience and social experience. The two dimensions of co-creation experience have a significant positive impact on citizenship behaviors and have a mediating effect.

$\mathrm{H} 2 \mathrm{~b}$ is not supported by the data. The reason why task-relevant clues did not have a significant effect on cognitive experience may be: 1) because of different motivations, the respondents took part in product design and promotion in order to gain enjoyment and interaction rather than knowledge of the use of the product; 2) the participates degree of the subjects in the sample is not high; 3) in addition, task-related clues of the virtual brand community website did not meet the requirements of customers when they were involved in the value co-creation activities. The reason why $\mathrm{H} 4 \mathrm{~b}$ is not supported by data may be that the respondents' participation in co-creation activities does not make them well aware of cognitive satisfaction. In other words, the cognitive experience is not one of the purposes of the customer's participation in value co-creation activities.

Our findings extend previous studies (Parboteeah et al., 2009), suggesting that affection-relevant cues have a greater effect on co-creation experience and are more important for stimulating hedonic experience. Previous studies have pointed out that the value of information is an important motive for influencing consumers' participation in the community (Zhou, Wu, Zhang et al., 2013). In fact, entertainment is the important motivation for consumer to participate in virtual brand community. The findings are consistent with those of previous studies indicating that hedonic value is the most prominent driver of the use of hedonic systems (Zhang, Lu, Wang et al., 2015; Verleye, 2015). Thus, customers primarily participate in co-creation activities to attain a positive psychological state of enjoyment, namely, a hedonic experience. Some scholars believe that enterprises can use entertainment content in the community to enhance consumer awareness of the brand (Vries, Gensler, Leeflang, 2012). Previous studies have shown that a good community experience can drive formation of customers' positive attitude towards products and companies (Nambisan \& Baron, 2009). Similarly but differently, the study has proved the positive effect of co-creation experience on customer citizenship behavior.

\subsection{Theoretical Contributions and Managerial Implications}

Research on value co-creation has attracted the attention of marketing scholars, especially research based on virtual brand community. However, most of the relevant research is from the enterprise point of view, such as the impact of customer participation on service innovation performance, the impact of value co- 
creation on brand assets. A few scholars study from consumers' experience value perspective and explore the influencing factors of this experience. The number of papers on re-understanding of the service experience has been increasing in the past two years, and a few articles have explored the concept of co-creation experience. So this study makes an empirical analysis, from aspects of Individuals and enterprises to find co-creation experience's impact factors. The results of this study can help enterprises better manage customer participation, as well as pay attention to improve the co-creation experience.

When newly developed products and services need to meet different customers' personalized value requirements, companies should encourage more customers to participate in, create opportunities and organize co-creation activities to increase customer participation. Customer participation can improve their awareness of co-creation experience, resulting in citizenship behavior. Customers come up with customized or improved design concepts based on individual needs or product experience. Their recommendations can be collected into the product update preparation stage by companies. In view of affection-related clues compared to task-relevant clues creating a more comprehensive impact on the co-creation experience, enterprises can give priority to update the site design and improve the attractiveness and novelty of the site in the site optimization. Besides, a reasonable set of forum structure and content should be arranged in virtual brand community to increase customer awareness of cognitive experience.

\subsection{Limitations and Future Research Directions}

Most of the respondents are members in the millet community, so there are some limitations in sampling. The study divided co-creation experience in virtual brand community into three dimensions, which may differ under different contexts. The applications of three dimensions need to be verified by further research. Because this research mainly uses the method of questionnaire, which is subjective sometimes and it can easily affect the objectivity of the research conclusion, the future study on co-creation experience and customer citizenship behavior in virtual brand community can combine experimental method with case analysis to come to a comprehensive and scientific conclusion.

This study did not examine the probable influence of other variables such as community type, customer characteristics, loyalty, product or service attributes. Customers who have high recognition for virtual brand community are mostly brand loyal customers. They generally have more knowledge related to products or services, and pay more attention to the long-term development of company. Compared with general customers in the community, they tend to have a stronger customer citizenship behavior intention and obtain psychological satisfaction and a sense of accomplishment through recommendation, help, feedback and other actions. The further research can also take other variables into consideration as moderators, such as such as customer innovation, self-efficiency and so on. 


\section{References}

Ahearne, M., Bhattacharya, C. B., \& Gruen, T. (2005). Antecedents and Consequences of Customer-Company Identification: Expanding the Role of Relationship Marketing. Journal of Applied Psychology, 90, 574-585. https://doi.org/10.1037/0021-9010.90.3.574

Bettencourt, L. A. (1997). Customer Voluntary Performance: Customers as Partners in Service Delivery. Journal of Retailing, 73, 383-406.

Bove, L. L., Pervan, S. J., Beatty, S. E. et al. (2009). Service Worker Role in Encouraging Customer Organizational Citizenship Behaviors. Journal of Business Research, 62, 698-705.

Eroglu, S. A., Machleit, K. A., \& Davis, L. M. (2001). Atmospheric Qualities of Online Retailing: A Conceptual Model and Implications. Journal of Business Research, 54, 177-184. https://doi.org/10.1016/S0148-2963(99)00087-9

Gentile, C., Spiller, N., \& Noci, G. (2007). How to Sustain the Customer Experience: An Overview of Experience Components That Co-create Value With the Customer. European Management Journal, 25, 395-410. https://doi.org/10.1016/j.emj.2007.08.005

Groth, M. (2005). Customers as Good Soldiers: Examining Citizenship Behaviors in Internet Service Deliveries. Journal of Management, 31, 7-27. https://doi.org/10.1177/0149206304271375

Gruen, T. W. (1995). The Outcome Set of Relationship Marketing in Consumer Markets. International Business Review, 4, 447-469.

Huizingh, E. K. R. E. (2000). The Content and Design of Web Sites: An Empirical Study. Information \& Management, 37, 123-134. https://doi.org/10.1016/S0378-7206(99)00044-0

Keh, H. T., \& Chi, W. T. (2001). Retail Customers as Partial Employees in Service Provision: A Conceptual Framework. International Journal of Retail \& Distribution Management, 29, 370-378. https://doi.org/10.1108/09590550110396944

Liang, T. P., Ho, Y. T., Li, Y. W. et al. (2011). What Drives Social Commerce: The Role of Social Support and Relationship Quality. International Journal of Electronic Commerce, 16, 69-90. https://doi.org/10.2753/JEC1086-4415160204

Lindgaard, G., Fernandes, G., Dudek, C. et al. (2006). Attention Web Designers: You Have 50 Milliseconds to Make a Good First Impression! Behaviour \& Information Technology, 25, 115-126. https://doi.org/10.1080/01449290500330448

Liu, Y., Li, H., \& Hu, F. (2013). Website Attributes in Urging Online Impulse Purchase: An Empirical Investigation on Consumer Perceptions. Decision Support Systems, 55, 829-837.

Muniz, A. M., \& O’Guinn, T. C. (2001). Brand Community. Journal of Consumer Research, 27, 412-432. https://doi.org/10.1086/319618

Nambisan, S., \& Baron, R. A. (2009). Virtual Customer Environments: Testing a Model of Voluntary Participation in Value Co-creation Activities. Journal of Product Innovation Management, 26, 388-406. https://doi.org/10.1111/j.1540-5885.2009.00667.x

Parboteeah, D. V., Valacich, J. S., \& Wells, J. D. (2009). The Influence of Website Characteristics on a Consumer's Urge to Buy Impulsively. Information Systems Research, 20, 60-78. https://doi.org/10.1287/isre.1070.0157

Payne, A. F. (2008). Managing the Co-Creation of Value. Journal of the Academy of Marketing Science, 36, 83-96. https://doi.org/10.1007/s11747-007-0070-0

Prahalad, C. K., \& Ramaswamy, V. (2000). Co-Opting Customer Competence. Harvard Business Review, 78, 79-90. 
Prahalad, C. K., \& Ramaswamy, V. (2004). Co-Creation Experiences: The Next Practice in Value Creation. Journal of Interactive Marketing, 18, 5-14.

https://doi.org/10.1002/dir.20015

Ren, Y., Harper, F. M., Drenner, S. et al. (2012). Building Member Attachment in Online Communities: Applying Theories of Group Identity and Interpersonal Bonds. MIS Quarterly, 36, 841-864.

Rosenbaum, M. S., \& Massiah, C. A. (2007). When Customers Receive Support from Other Customers: Exploring the Influence of Customer Social Support on Customer Voluntary Performance. Journal of Service Research, 9, 257-270. https://doi.org/10.1177/1094670506295851

Schau, H. J., Muñiz, A. M., \& Arnould, E. J. (2009). How Brand Community Practices Create Value. Journal of Marketing, 73, 30-51.

https://doi.org/10.1509/jmkg.73.5.30

Van Doorn, J., Lemon, K. N., Mittal, V. et al. (2010). Customer Engagement Behavior: Theoretical Foundations and Research Directions. Journal of Service Research, 13, 253 266. https://doi.org/10.1177/1094670510375599

Verleye, K. (2015). The Co-Creation Experience from the Customer Perspective: Its Measurement and Determinants. Journal of Service Management, 26, 321-342. https://doi.org/10.1108/JOSM-09-2014-0254

Vries, L. D., Gensler, S., \& Leeflang, P. S. H. (2012). Popularity of Brand Posts on Brand Fan Pages: An Investigation of the Effects of Social Media Marketing. Journal of Interactive Marketing, 26, 83-91.

Yi, Y., \& Gong, T. (2013). Customer Value Co-Creation Behavior: Scale Development and Validation. Journal of Business Research, 66, 1279-1284.

Zhang, H., Lu, Y., Wang, B. et al. (2015). The Impacts of Technological Environments and Co-Creation Experiences on Customer Participation. Information \& Management, 52, 468-482. https://doi.org/10.1016/j.im.2015.01.008

Zhao, X., Lynch, J. G., \& Chen, Q. (2010). Reconsidering Baron and Kenny: Myths and Truths about Mediation Analysis. Journal of Consumer Research, 37, 197-206. https://doi.org/10.1086/651257

Zhou, Z., Wu, J. P., Zhang, Q. et al. (2013). Transforming Visitors into Members in Online Brand Communities: Evidence from China. Journal of Business Research, 66, 2438-2443. 
Submit or recommend next manuscript to SCIRP and we will provide best service for you:

Accepting pre-submission inquiries through Email, Facebook, LinkedIn, Twitter, etc. A wide selection of journals (inclusive of 9 subjects, more than 200 journals)

Providing 24-hour high-quality service

User-friendly online submission system

Fair and swift peer-review system

Efficient typesetting and proofreading procedure

Display of the result of downloads and visits, as well as the number of cited articles Maximum dissemination of your research work

Submit your manuscript at: http://papersubmission.scirp.org/

Or contact aasoci@scirp.org 